\title{
THE IMPACT OF POPULATION DENSITY ON BODY CONDITION OF NEWFOUNDLAND ADULT WILLOW PTARMIGAN
}

\author{
Chris T. Callahan ${ }^{1}$, J. Michael McGrath ${ }^{2}$, \\ Gerard LeONARD ${ }^{3}$, AND Alex MurLeY ${ }^{3}$ \\ ${ }^{1}$ Wildlife Division, Department of Environment and Conservation, Government of \\ Newfoundland and Labrador, P.O. Box 2007, Corner Brook, \\ Newfoundland/Labrador A2H 7S1 Canada \\ E-mail: chriscallahan@gov.nl.ca \\ ${ }^{2}$ Wildife Division, Department of Environment and Conservation, \\ Government of Newfoundland and Labrador, P.O. Box 8700, Building 810, \\ Pleasantville, Newfoundland/Labrador A1B 4J6 Canada \\ ${ }^{3}$ Forestry Services Branch, Department of Natural Resources, \\ Government of Newfoundland and Labrador, P.O. Box 340, Pasadena, \\ Newfoundland/Labrador AOL 1 KO Canada
}

\begin{abstract}
We compared average weights of sampled Willow Ptarmigan (Lagopus lagopus alleni) to corresponding fall abundance (1975-2010) to assess the potential role of population abundance on body condition. Ptarmigan abundance was measured as birds seen per kilometer walked, and average weights were from a random harvested sample of the birds. We found an apparent negative relationship between Willow Ptarmigan abundance and average adult female and male weights. Importantly, previous data indicate that the island of Newfoundland has one of the lowest breeding densities of Willow Ptarmigan within its range. Newfoundland's marginal habitat may limit the ability of Willow Ptarmigan to reach densities similar to the rest of its range as expressed negatively through body condition. Received 7 January 2011, accepted 31 January 2011 .

Callahan, C. T., J. M. McGrath, G. Leonard, and A. Murley. 2011. The impact of population density on body condition of Newfoundland adult Willow Ptarmigan. Abstract, page 273 in R. T. Watson, T. J. Cade, M. Fuller, G. Hunt, and E. Potapov (Eds.). Gyrfalcons and Ptarmigan in a Changing World, Volume I. The Peregrine Fund, Boise, Idaho, USA. http://dx.doi.org/ 10.4080/gpcw.2011.0128
\end{abstract}

Key words: Density dependence, body condition, Newfoundland, Willow Ptarmigan. 
- Callahan et Al. - 